\title{
Agro Pastoralist's Perception and Willingness to Participate in Water Harvesting Practices in South Omo Zone, Southern Ethiopia
}

\author{
Asmera Adicha ${ }^{1, *}$, Melkamu Mada ${ }^{2}$ \\ ${ }^{1}$ Socioeconomics Research, Technology Transfer and Seed Multiplication Directorate, Southern Agricultural Research Institute, Jinka \\ Agricultural Research Center, Jinka, Ethiopia \\ ${ }^{2}$ Departments of Economics, College of Business and Economics, Arba Minch University, Arba Minch, Ethiopia
}

Email address:

asmera05@gmail.com (A. Adicha),melkamumada2002@gmail.com (M. Mada)

${ }^{*}$ Corresponding author

\section{To cite this article:}

Asmera Adicha, Melkamu Mada. Agro Pastoralist's Perception and Willingness to Participate in Water Harvesting Practices in South Omo Zone, Southern Ethiopia. American Journal of Agriculture and Forestry. Vol. 8, No. 5, 2020, pp. 223-234. doi: 10.11648/j.ajaf.20200805.16

Received: March 25, 2020; Accepted: April 10, 2020; Published: October 27, 2020

\begin{abstract}
This study was conducted to assess agro pastoralist's perception and willingness to participate in water harvesting practices that could improve their decision to construct and manage water storage technologies at individual household level or community level in the study area. A total of 192 agro pastoralist's households were assessed and $92.7 \%$ of them were willing to participate in rainwater harvesting practices and the rest $7.3 \%$ were not. Of the willing respondents $27.53 \%, 54.49 \%$ and $17.98 \%$ preferred clay lined pond, plastic lined pond and aboveground tank water storage technologies. And also the study specified the binary logistic for the participation decision and multinomial logistic for the choice decision model to identify factors that affect participation decision on water harvesting technologies and preference of water storage technologies. Accordingly, estimation of the binary logistic model showed that labor availability, distance to water source, perception towards water harvesting practice, age of respondent and credit services significantly affect the willingness of agro pastoralists to participate in water harvesting technologies. Whereas labour availability, ownership of plot, plot distance and area of particular plot affect the choice decision of agro pastoralists on rain water storage options among alternatives in the study area. It can be concluded that policy makers must give attention on factors affecting perception/participation decision of agro pastoralist's in water harvesting works and their preference among water storage options, and on gender issues in the planning/implementation of water harvesting activities.
\end{abstract}

Keywords: Water Harvesting, Perception, Participation, Binary \& Multinomial Logistic

\section{Introduction}

Water is essential for the environment, food security and sustainable development [1]. Access to water can make an immense contribution to health, productivity, and social development [2]. However, Water is becoming increasingly scarce because of climate change and population growths which lead to a drastic decline in the amount of water available in many parts of the developing world. As a result, millions of people throughout the world and most of peoples in Arid and Semi-arid parts of Africa do not have access to water; economic water scarcity is especially linked to low income and poverty [3]. Thus, to alleviate water shortage problem in the arid and semi-arid parts of the country which threatens the lives of millions of people, the important strategy is to store water. Water storage spurs economic growth and helps to alleviate poverty by making water available when and where it is needed [4].

South Omo zone is one of arid and semi-arid areas of South Nations Nationality and Peoples Regions in Ethiopia. In the area rainfall is both low and irregular which causes serious shortage of water for domestic consumption and livestock watering during severe dry seasons. As result, pastoralists or agro pastoralists are forced to travel long distances in search of water sources, especially women and girls, as they carry responsibility of collecting water. 
Benatsemay is one of the districts in the South omo zone and faces water shortage problems in both normal and severe drought season. This is due to erratic nature of rain fall in the area which causes water scarcity for both livestock and human being. In the district, lack of rain is accompanied by keen lack of water and grazing fodder which cause high animal death. [5] Reported that due to lack of rain fall, drying of water sources and depleted pastures caused problem on production and health of livestock. Moreover, livelihoods of pastoralist were worsening due to lose of productive animals and faced extreme difficulties in meeting their basic food and have been severely impacted. The deterioration of livestock production has had the most severe impact on their livelihoods due to the loss of their main source of income and food. As a result, government and some NGOs introduced community level rainwater harvesting technologies to store water for a long period to reduce water problems. They introduced surface ponds mainly clay lined pond on community land and plastic lined ponds on individuals farm in the area and residents of the district use for both domestic and animal's consumption.

Even though government and NGO introduced community level water harvesting technologies, water shortage problem for both human and livestock is serious. Even community level constructed surface ponds are filled by dirty materials and soils due to extensive and mobile grazing of livestock. This is due to no or little attention has been given on agro pastoralist's awareness creation on how to use and enable them to participate in rainwater harvesting technologies. Thus, the importance of the agro pastoralists' perception or participation has been ignored mainly by excluding them from the designing, implementation and assessment stages of the rainwater harvesting technologies. This also led to problems relating to low rates or poor adoption processes due to insufficient participation by the pastoralists targeted by the rainwater harvesting technologies.

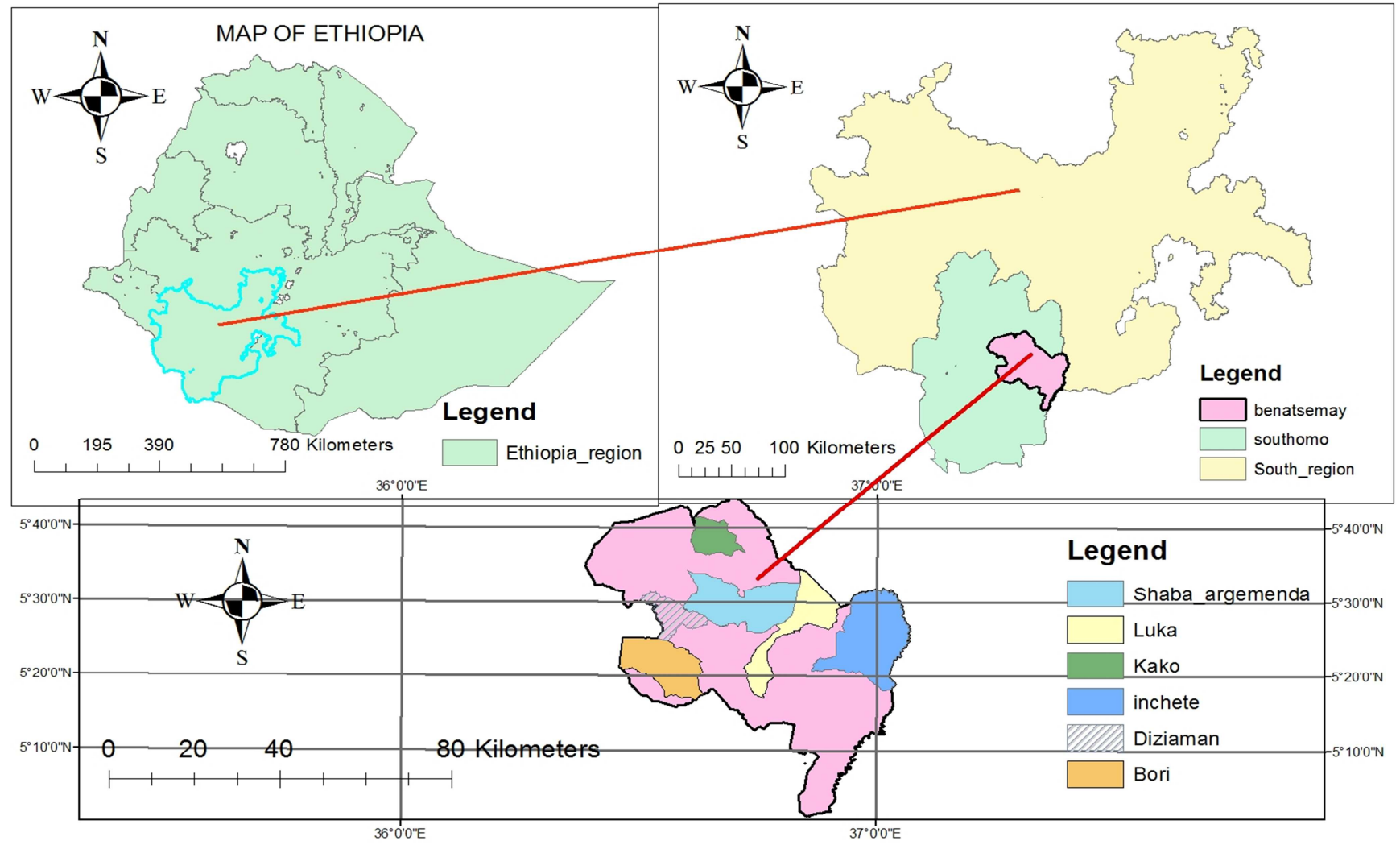

Source: own sketch, 2018

Figure 1. Map of the study area.

The success or failure of any rainwater harvesting technology will ultimately depend on the degree of acceptance by the land users. It is essential that the needs and aspirations of the land users are clearly understood and fully provided in the planning, designing and implementation process of any new technologies like water harvesting practices [6]. Thus, in the study area no empirical studies have been conducted on agro pastoralist's perception and willingness to participate in rainwater harvesting technologies. Therefore, objective of this study was to identify factors affecting agro pastoralist's willingness to participate in rain water harvesting technologies and their preferences on rain water storage technology options. Lastly to assess gender contribution on rain water harvesting technologies in the study area.

\section{Research Methodology}

\subsection{Description of the Study Area}

South omo zone is located at the southern part of the South 
Nation Nationalities and Peoples Region (SNNPR). Astronomically, it lies between $4^{\circ} 43^{\prime}$ North to $6^{\circ} 46^{\prime}$ North latitude \& $35^{\circ} 79^{\prime}$ East to $36^{\circ} 06^{\prime}$ East longitude. It is bordered by Keffa Zone and Konta Special woreda in North, Gamo Gofa zone and Basketo special woreda in North East, Kenya in South, Segen zuria people's zone in East, Oromia Region (Borena Zone) in South East, Bench Maji zone in West and North west and Sudan in South West direction and with an area coverage of $22,835.80 \mathrm{~km}^{2}$ [7]. Benatsemay district is one of the eight districts in the South Omo Zone administration which covers an area of $25490.7 \mathrm{Ha}$. It is bordered by Malle woreda in the East north, by Hammer woreda in West, by Konso woreda in East and by South Ari to the North direction. The woreda is situated between $5.01^{\circ}$ $5.73^{\circ} \mathrm{N}$ latitude and $36.38^{\circ}-37.07^{\circ} \mathrm{E}$ longitude.

\subsection{Data Types and Source}

Both qualitative and quantitative data types were collected from primary and secondary data sources. The primary data collected from household include information on: household demographic, socio-economic, land characteristics, institutional factors and other biophysical factors which were supposed to explain agro pastoralist's decision behavior concerning water harvesting participation. Secondary data sources used for this study were journals, relevant text books, government and non-government reports, South omo zone pastoralist areas farming and natural resource department, livestock and fishery resource department, and Benatsemay pastoral development office reports.

\subsection{Sampling Procedure}

In Benatsemay district rainwater harvesting technologies were promoted and practiced than other district and it was selected purposely for this study. A two-stage sampling technique was employed to draw sample household heads. In the first stage, out 30 Kebeles in the woreda 6 kebeles were randomly selected. At second stage, sample households from each sample kebeles were selected from the recent lists of households using probability proportional to size sampling technique. Given the relative homogeneity of households in terms of their socio- economic characteristics and livelihood style sample households were selected using simple random sampling method.

\subsection{Sample Size Determination}

To determine the appropriate sample size, the basic factors to be considered are the level of precision required by users, the confidence level desired and degree of variability. Thus, it was determined using a simplified formula provided by [8].

$$
\mathrm{n}=\frac{z 2 p q N}{e 2(N-1)+z 2 p q}
$$

Where: $\mathrm{n}$ : is the sample size for a finite population $\mathrm{N}$ : size of population which is the number of households in the Woreda p: population reliability (or frequency estimated for a sample of size $n$ ), where $p$ is 0.5 which is taken for all developing countries population and $\mathrm{p}+\mathrm{q}=1$ e: margin of error considered is $7 \%$ for this study because of budget constraint to collect large sample with margin of error $5 \%$. Z $\alpha / 2$ : normal reduced variable at 0.05 level of significance $z$ is 1.96. Accordingly sample size is determined as follows:

$$
\begin{gathered}
\mathrm{N}=10460 \mathrm{HHs} \\
\mathrm{n}=\frac{(1.96 \times 1.96) \times(0.5 \times 0.5) \times(10460)}{(0.07 \times 0.07) \times 10460+(1.96 \times 1.96) \times(0.5 \times 0.5)}=192
\end{gathered}
$$

\subsection{Methods of Data Collection}

Formal and informal methods of data collection tools were implemented to acquire primary data. Among the informal data collection tools key informant interview and focus group discussion with pre-defined social groups (elders, model agro pastoralists, women's, DAs) were conducted before formal survey to collect general information about the study area and farming system. Formal data collection was employed with the help of pre-tested structured interview schedule and observation of water harvesting practices in the area through transact walk.

\subsection{Method of Data Analysis}

Descriptive statistics and econometric models were used to describe variables and study the relationships between variables empirically. Moreover, for qualitative nature of responses, it is important to consider the binary response regression model. There are three approaches to develop a probability model for a binary response variable. In econometric literature for estimating binary choice models the linear probability model (LPM), logit and probit are the possible alternative models and have been commonly used for a binary response variable [9]. The weakness of linear probability model are the predicted probability may lie outside the neutral interval $(0 \leq p \leq 1)$, both Yi and Ui do not follow normal distribution but they follow Bernoulli distribution and the error term (Ui) is heterocedastic.

To overcome the problems with the linear model, there exists a class of binary choice models (or univariate dichotomous models), designed to model the 'choice' between two discrete alternatives. These models essentially describe the probability that $\mathrm{y}_{\mathrm{i}}=1$ directly, although they are often derived from an underlying latent variable model. Common choices are the standard normal distribution function (probit and logit) which are more common in applied work. Both a standard normal and a standard logistic random variable have an expectation of zero and these two distribution functions are very similar but the logistic distribution has slightly heavier tails. Accordingly, the probit and logit model typically yield very similar results in empirical work [10]. Though logit and probit yield similar parameter estimates, a cumulative logistic regression model is preferred because of its comparative mathematical simplicity [11]. Thus, this study was used the binary logistic model to identify factors that affect the willingness of agro pastoralists to participate in water harvesting practices and multinomial logistic was used to assess the choice/preference decision of households among alternative water harvesting storage options. 


\section{Binary logistic model}

In participation decision studies, responses to a question such as whether agro pastoralists are willing to participate in a given technology could be 'yes' or 'no', a typical case of dichotomous variable. The dependent variable i.e., participation in water harvesting practice is dichotomous in nature and can be represented by dummy variables. i.e. 1 if they willing to participate in water harvesting practice and 0 if they do not. The independent variables are; labour availability, education level, sex of household head, age of household head, perception towards water harvesting, farm size, distance to water source, food shortage, credit access, training, distance to development center and livestock ownership.

\section{Multinomial logistic regression}

In several cases, there is no natural ordering in the alternatives and it is not realistic to assume that there is a monotonic relationship between one underlying latent variable and the observed outcomes [10]. While choosing water harvesting storage structure groups, there is no natural ordering in the alternatives. So choice lies in between multinomial logit and probit model. A multinomial probit model is less restrictive than the multinomial logit model. However, the multinomial probit model is gained at considerable computational expenses. The main obstacle to implementation of the Multinomial Probit model has been the difficulty in computing the multivariate normal probabilities for any dimensionality higher than two [12]. So, multinomial logit model was used for its simplicity of interpretations. The dependent variable for this analysis was water storage technology among which users decided to construct/use. Hence, a value 1 was assigned to represent clay lined pond, a value 2 represents plastic lined pond such as geo-membrane lined and trapezoidal pond, and a value 3 represents aboveground structure (Ferro cemented, tanker, etc.). The independent variables are; labour availability, education level, plot distance, plot area, livestock ownership, financial constraints, slope of plot, and ownership of plot.

\section{Results and Discussion}

\subsection{Results of Descriptive Statistics Analysis Participation Decision on Water Harvesting Technology}

As revealed in survey result 178 agro pastoralist or $92.7 \%$ of the total respondents were expressed their willingness to participate in constructing water harvesting structures by supplying labor force and covering some costs, whereas 14 agro pastoralist or $7.3 \%$ of the respondents were non-willing to participate in water harvesting technologies because they situated near river and landscape (steep slope) and is not suitable to construct water harvesting structures.

Table 1. Participation decision on water harvesting technology.

\begin{tabular}{lll}
\hline Participation decision & Frequency & Percent \\
\hline Willing & 178 & 92.7 \\
Non-willing & 14 & 7.3 \\
Total & 192 & 100 \\
\hline
\end{tabular}

Source: own survey (2018)

Preference analysis for water storage technology options

Considering local community's interest and water harvesting structures being practiced in the study area at the moment, this study categorized three storage groups namely above ground tank, clay lined and plastic lined pond. Willing respondents were identified in participation decision and they were asked to reveal their preferences among water storage technology groups. Of the entire total willing agro pastoralist, 32 (17.98 \%), 97 (54.49\%), and $49(27.53 \%)$ preferred clay lined pond, plastic lined pond and aboveground tank respectively

Table 2. Preference of water storage technology groups.

\begin{tabular}{lll}
\hline Preference & Frequency & Percent \\
\hline Clay lined pond & 32 & 17.98 \\
Plastic lined pond & 97 & 54.49 \\
Above ground tank & 49 & 27.53 \\
Total & 178 & 100 \\
\hline
\end{tabular}

Source, own survey (2018)

Awareness, perception and benefits of water harvesting practice

Awareness towards water harvesting: Almost all agro pastoralists have good awareness about the benefits that can be obtained from using water harvesting as supplementary water sources for livestock and agricultural activities. About $85.94 \%$ of them expressed RWH could help to mitigate severity of impacts of drought on people and livestock. As it is presented in table 3, 98.44\% of the sample households are aware of the benefits obtained from the water harvesting. They also reported that water harvesting is important in securing food supply and generating income to their family through using irrigation and also good means of tackling the impacts of drought. The chi-square test also shows systematic relation between importance of RWH in securing food supply and willingness to participate in water harvesting activities.

Table 3. Awareness of sample households on the benefits of water harvesting.

\begin{tabular}{llll}
\hline \multirow{2}{*}{ Attributes } & Willing & Non willing & Total \\
\cline { 2 - 4 } & N (\%) & N (\%) & N (\%) \\
\hline RWH is means of tackling the impacts of droughts & & & \\
Yes & $155(80.7)$ & $10(5.21)$ & $165(85.94)$ \\
No & $23(11.98)$ & $4(2.08)$ & $27(14.06)$ \\
RWH is means of securing food supply & & & \\
\hline
\end{tabular}




\begin{tabular}{lllll}
\hline \multirow{2}{*}{ Attributes } & Willing & Non willing & Total & $\chi \mathbf{2}$-value \\
\cline { 2 - 5 } & $\mathbf{N}(\mathbf{\%})$ & $\mathbf{N}(\mathbf{\%})$ & $\mathbf{N}(\mathbf{\%})$ & \\
\hline Yes & $178(92.71)$ & $11(5.73)$ & $189(98.44)$ & $38.75^{* * *}$ \\
No & $0(0.00)$ & $3(1.56)$ & $3(1.56)$ & \\
\hline
\end{tabular}

Source: Own Survey, 2018, NS= Non-significant, ${ }^{* * *}$ significant at $1 \%$ level

Perception towards water harvesting activities: For appropriate implementation of any technology agro pastoralists need to be conscious and responsive to effectively utilize the given technology. Respondents agreed that rain fed agriculture is insufficient to feed their family and water harvesting is economically important. Of the total sample respondents 96.9 percent agreed that water harvesting is important to supplement rain fed because rain fed agriculture is insufficient to supply water for livestock, human consumption and crop production since drought and erratic rain fall is common. In the study area the perceptions about the importance of water harvesting was somehow good and information through extension agent and some NGOs were available. As can be seen from table 4 , about $98.44 \%$ agreed that each family has to participate in water harvesting to secure food, of whom $91.15 \%$ willing and $5.73 \%$ non-willing participant. A chi-square test also showed a significant association between each family has to participate in water harvesting to secure food and rain fed agriculture is insufficient to feed their family at $1 \%$ probability level.

Table 4. Perception of sample pastoralists on water harvesting.

\begin{tabular}{|c|c|c|c|c|c|c|c|}
\hline \multirow{2}{*}{ Attributes } & \multicolumn{2}{|c|}{ Willing } & \multirow{2}{*}{$\begin{array}{l}\text { Non willing } \\
\text { No } \\
\end{array}$} & \multicolumn{2}{|l|}{ Total } & \multicolumn{2}{|c|}{$\chi 2$-value } \\
\hline & No & $\%$ & & $\%$ & No & $\%$ & \\
\hline \multicolumn{8}{|c|}{ Rain fed agriculture is insufficient to feed your family } \\
\hline Agree & 175 & 91.15 & 11 & 5.73 & 186 & 96.9 & \multirow{3}{*}{$16.72 * * *$} \\
\hline Disagree & 3 & 1.56 & 3 & 1.56 & 6 & 3.12 & \\
\hline Total & 178 & 92.71 & 14 & 7.29 & 192 & 100 & \\
\hline \multicolumn{8}{|c|}{ Each family has to participate in $\mathrm{WH}$ to secure food } \\
\hline Agree & 178 & 2.71 & 11 & 5.73 & 189 & 98.4 & \multirow{3}{*}{$38.75^{* * *}$} \\
\hline Disagree & 0 & 0.00 & 3 & 1.56 & 3 & 1.56 & \\
\hline Total & 178 & 92.71 & 14 & 7.29 & 192 & 100 & \\
\hline
\end{tabular}

Source: Own survey, $2018 * * *$ significant at $1 \%$ level

Training: training users and follow up are preconditions to make decisions to participate in water harvesting practices. In this study, components of training such as field visit, and demonstration of water harvesting practices which will improve agro pastoralist's knowledge and skills on construction and maintenance of water harvesting technology structures were assumed to improve effective utilization of water harvest technology. However, training and visiting in different water harvesting activities are not commonly practiced in the study area. As provided in survey result in table 5, 150 sample household heads or $78.1 \%$ haven't participated in training and other water harvesting related matters. Of the total those who have not trained and participated respondent $71.3 \%$ and $6.8 \%$ were willing and non-willing agro pastoralist's households respectively.

Table 5. Training in water harvesting activities by sample households heads.

\begin{tabular}{llllllll}
\hline Training & Willing & & Non- willing & Total & & $\chi$ 2-value \\
\hline & No & $\%$ & No & $\%$ & No & $\%$ & \\
Yes & 41 & 21.4 & 1 & 0.5 & 42 & 21.9 & 1.92 (NS) \\
No & 137 & 71.3 & 13 & 6.8 & 150 & 78.1 & \\
Total & 178 & 92.7 & 14 & 7.3 & 192 & 100 & \\
\hline
\end{tabular}

Source: Own Survey, 2018, NS= Non-significant

\section{Gender aspects}

In the study area traditionally women's manage water in the clay lined ponds and play a crucial rule in water provision. They participate in the decision-making of water supply and demand for the families as well fetching water is more the responsibility of the women than men. It is also the responsibility of women to make sure that the children have food and the animals are well watered. But the men do the maintenances if disturbed by overgrazing of livestock's and in some instance (very drought seasons) males are responsible for livestock watering than women's. As shown in table $6,83.85 \%$ of respondents reported that in their house females are responsible to fetch water of whom $77.6 \%$ are willing and $6.25 \%$ are not willing to participate in water 
harvesting activities. Moreover, sample households also reported that their children fetch water for household consumption $16.2 \%$ of whom $15.10 \%$ from willing and $1.04 \%$ from non-willing to participate in water harvesting activities. Chi-square comparison between willing and nonwilling groups in this regard showed no systematic association. As affirmed in focus group discussion, in all agro pastoral groups watering and feeding of livestock is the responsibility of all family members. Children and women participate in herding sick, lactating small ruminants, some kids and lambs. During dry season men's care more about livestock watering because they are physically strong than women's to travel a long distance in search of water. As water harvesting works are tedious and laborious most of time male headed household heads practice water harvesting than female headed because female headed household have many other household responsibilities. From table below, of the total respondents $56.3 \%$ revealed that male headed are effective than female headed. About $25.5 \%$ revealed female headed are effective in water harvesting work than male and $18.2 \%$ of respondents also raised both are effective if they practice efficiently. A chi-square comparison also showed the existence of systematic association between willing to participate in water harvesting activities and effectiveness of male headed or female headed household in using water harvesting at less than $5 \%$ probability level and a chi-square value of 8.10 .

Table 6. Gender contribution by sample households in water harvesting activities.

\begin{tabular}{|c|c|c|c|c|c|c|c|}
\hline \multirow{2}{*}{ Response } & \multicolumn{2}{|c|}{ Willing } & \multicolumn{2}{|c|}{ Non willing } & \multicolumn{2}{|c|}{ Total } & \multirow{2}{*}{$\chi 2$-value } \\
\hline & No & $\%$ & No & $\%$ & No & $\%$ & \\
\hline \multicolumn{8}{|l|}{ Fetching of water } \\
\hline Children & 29 & 15.1 & 2 & 1.04 & 31 & 16.2 & \multirow[t]{2}{*}{0.039 (NS) } \\
\hline Total & 178 & 92.7 & 14 & 7.3 & 192 & 100 & \\
\hline $\begin{array}{l}\text { Effectiveness of household } \\
\text { male headed household }\end{array}$ & 104 & 54.1 & 4 & 2.08 & 108 & 56.3 & \multirow{4}{*}{$8.1024 * *$} \\
\hline female headed household & 41 & 21.4 & 8 & 4.17 & 49 & 25.5 & \\
\hline Both & 33 & 17.2 & 2 & 1.04 & 35 & 18.2 & \\
\hline Total & 178 & 92.7 & 14 & 7.29 & 192 & 100 & \\
\hline
\end{tabular}

Source: Survey data, 2018, NS= Non-significant, **represents level of significance at 5\%.

\subsection{Econometric Results}

\section{Econometric results of binary logistic model}

Important explanatory variables that were expected to have impact on the decision of a given agro pastoralist to participate in water harvesting works were selected based on literature review and used to estimate the binary logistic regression model to analyze the factors affecting household's willingness to participate in water harvesting works. A binary logistic regression model was fitted to estimate the effect of hypothesized explanatory variables on the probabilities of being willing to participate or not. STATA 12 was used for the econometric analysis. Diagnostic tests were conducted, in which multicollinearity problem was detected. Later, explanatory variables resulting in multicollinearity problem were omitted, and the result of the analysis is presented in Table 7 below. The maximum likelihood estimates of the binary logistic model result showed that the household's willingness to participate in water harvesting activities was affected by the interaction of several potential socioeconomic, institutional and demographic factors. To check measure of goodness of fit in logistic regression analysis, the likelihood ratio test (LR) that follows chi-square distribution with degree of freedom (DF) equal to number of explanatory variables included in the model [9]. Accordingly, the chisquare computed shows that the model was significant at $1 \%$ significance level. This indicates that the null hypothesis stating the coefficients of explanatory variables less the intercept are equal to zero was rejected and the alternative hypothesis of non- zero slope was accepted. The value of chi -square test shows the overall goodness of fit of the model at less than $1 \%$ probability level. In addition, pseudo $\mathrm{R}^{2}$ was found to be 0.6317 .

Of the twelve explanatory variables used in the model, 5 variables found to have a significant effect on the willingness of a given pastoralist or agro pastoralist to participate in water harvesting activities at $1 \%$ and $5 \%$ significance level. Access to credit services was significant at $1 \%$, distance to water source in minute, perception towards water harvesting practices, labor availability in man equivalent and age of household head were significantly affect willingness of agro pastoralist to participate in water harvesting activities at 5\% probability level. The rest 7 variables were not significant at less than $10 \%$ probability level.

Age of household head: is significant at 5\% significance level and has negative association with willingness of agro pastoralist to participate in water harvesting activities. The negative effect of this variable indicates that aged peoples are less willing to participate in water harvesting activities than the younger. Holding influences of other factors constant, as age of household head increases by one more year, the likely probability to participate in water harvesting activities decreases by a factor of 0.850 . Study by [13], revealed that adoption of rainwater harvesting technology for home garden 
found similar result with this study.

Credit access: Accessibility of credit facilities is a prerequisite for a technology to be adopted and promoted properly. It was significant at $1 \%$ level and positively related to the willingness of agro pastoralist to participate in water harvesting activities. This result agreed with what was expected earlier in the hypothesis that access to credit facilities relaxes financial constraints of agro pastoralist to participate in any water harvesting activities. The positive relationship indicates that the odds ratio in favor of the probability of being willing increases with an increase in access to credit facilities. [14] Reported similar results that cash availability has positive relation to the utilization of rainwater harvesting technology by farmers. The odds ratio of 1.008 for credit access implies that, other things being constant, the odds ratio in favor of being willing increases by a factor of 1.008 as credit access increases by a unit. On the other hand, the willingness to participate in water harvesting activities increases by a factor of 1.008 as availability of credit access increased by one unit.

Labour availability (man equivalent): is significant at 5\% and positively related with the willingness of agro pastoralists to participate in water harvesting works indicating that an increase in labour allows agro pastoralists to achieve large labour force. This result was consistent with many other research results which were conducted in earlier times as well as agrees with the ideas mentioned in the hypothesis part of this thesis. [15] Reported availability of labour as an important element for the promotion of water harvesting works. With the assumption of constant influences of other factors, the odds ratio indicates that the probability of being willing to participate in water harvesting work increases by a factor of 2 as labour availability increases by one man equivalent unit.

Distance to water sources: This variable is significant at $5 \%$ level and related positively with the willingness of agro pastoralists to participate in water harvesting works. The result is consistent with the idea in the hypothesis, which means those agro pastoralists who are nearby the water source may have more access to water for their household consumption, livestock and crop watering than those who are distant to water sources. As they are located at near the water source they are non-willing to participate in water harvesting activities than distant to water sources. On the contrary those distant to water sources are more willing to participate in water harvesting activities. The odds ratio 1.07 indicate that with the assumption of ceteris paribus, the willingness of agro pastoralist gets increasing by a factor of 1.07 as distance of homestead to water source increases by 1 minutes waking time.

Perception_WH: Agro pastoralist's perception towards rain water harvesting was a statistically-significant at 5\% level and positive effect on participation decision of water harvesting, i.e., agro pastoralist's who have positive perception towards rain water harvesting technologies are more likely willing to participate. The odds ratio for perceptions towards rainwater harvesting was 57.06 implying that the effects of other factors kept constant, a famer who has a positive attitude is more likely willing to participate in rain water harvesting technologies at 57.06 times the odds of a pastoralist who has a negative attitude. This result is consistent with a priori expectations and the findings of [13]. A positive perception towards an innovation by a household is expected to lead to subsequent adoption of such technology.

Table 7. The maximum likelihood estimates of the binary logistic model.

\begin{tabular}{|c|c|c|c|c|}
\hline Variables name & Estimated coefficient (B) & Odds ratio & $\mathbf{P}>|\mathbf{z}|$ & Std. err \\
\hline Age & -0.162 & 0.850 & $0.021 * *$ & 0.07 \\
\hline Sex & -1.416 & 0.243 & 0.643 & 3.059 \\
\hline Food shortage & -0.910 & 0.402 & 0.416 & 1.118 \\
\hline Training & 0.139 & 1.149 & 0.911 & 1.24 \\
\hline Man equivalent & 0.694 & 2.001 & $0.024 * *$ & 0.308 \\
\hline Dist_Water & 0.068 & 1.070 & $0.020 * *$ & 0.029 \\
\hline TLU & -0.073 & 0.929 & 0.166 & 0.053 \\
\hline Dist-Dev-center & -0.055 & 0.946 & 0.239 & 0.047 \\
\hline Farm Size & 0.460 & 1.585 & 0.412 & 0.562 \\
\hline Credit Access & 0.008 & 1.008 & $0.001 * * *$ & 0.002 \\
\hline Education & -0.129 & 0.878 & 0.578 & 0.233 \\
\hline Percept WHT & 4.044 & 57.059 & $0.033 * *$ & 1.899 \\
\hline
\end{tabular}

Source: model output

Logistic regression Number of Obs $=192$

LR chi2 $(12)=63.34$

Prob $>$ chi $2=0.0000$

Log likelihood $=-18.464035$ Pseudo R2 $=0.6317$

$* * *, * *$ Indicate significance at $1 \%$, and $5 \%$ level respectively 
multicollinearity problem was detected and also test of the IIA assumption was performed using Hausman's test procedure using STATA 12 software package. The result of the test provided an evidence that outcome-J versus outcome-K are independent of other alternatives. Moreover, explanatory variables resulting in multicollinearity problem were omitted, and the result of the analysis is summarized in table 8 below. The likelihood ratio chi-square value of 139.71 with a p-value of 0.000 tells us that likelihood ratio test statistics exceeds the Chi-square critical value at less than $1 \%$ probability level. This implies that the hypothesis, which says all coefficients except the intercept is zero, was rejected. The value of Pearson Chisquare test shows the overall goodness of fit of the model at less than $1 \%$ probability level. Besides, pseudo $\mathrm{R}^{2}$ was found to be 0.3946 . The plastic lined pond water storage technology choice was the most frequently occurring outcome and set by model as a reference outcome. However, reference category can be the most or least frequently occurring outcome [16]. This study used the least frequently occurred outcome as a reference category so as the result would enable us to make comparison among the other two important but usually not practiced in most of agro pastoralist farm. Thus, the reference category clay lined pond was practiced by most of agro pastoralist farm and is used as comparison group to two most important water harvesting technology groups.

Of the 8 explanatory variables considered as factors for the choice decision of sample households among different water storage technology groups, 4 variables namely labour availability, ownership of plot, plot area and plot distance were significant at $10 \%$ and $1 \%$ probability level. Accordingly, labour availability was found to have significant impact on the choice decision of plastic lined pond at $10 \%$ probability level. Ownership of plot and plot area were found to have significant impact on the choice decision of aboveground tank at $10 \%$ and $1 \%$ probability level respectively. Plot distance was significantly affect choice of both plastic lined pond and aboveground tank storage at $1 \%$ probability level. The effect of some significant variables is not similar for each storage groups. Some may be highly significant to affect the choice decision for a particular group and insignificant for the other groups. Coefficients of the MNL model explain the direction of change of the dependent variable as explanatory variables change. To provide the effects of independent variables on the dependent variable, estimates of marginal effects which measure the expected change in probability of a particular choice being made with respect to a unit change in an independent variable were reported in Table 9.

Multinomial logit result showed that plot distance from home stead, ownership of land or plot, labour availability of household head and area of particular plot were important variables that significantly explained choice of most preferred water storage technology groups. More particularly each variable were explained as follow.

Labour availability (Man Equivalent): It was found significant at $10 \%$ probability level and positively affects choice of plastic lined pond of water harvesting technology over its base category. As revealed in the model result, on average, an increase of man equivalent of agro pastoralist by one unit would result in the increase of the likelihood of choosing plastic lined pond over clay lined pond of water harvesting technology by $2.9 \%$. This means that agro pastoralists who have large labour force would prefer plastic lined pond over clay lined pond of water harvesting technology. This is because using plastic lined pond water harvesting technology is more labours work and comparatively important for livestock watering, human consumption and crop production than clay lined pond and requires more labour force for activities such as irrigation, drinking water for humans and livestock. This result was consistent with other research results, which were conducted in earlier times as well as agrees with the ideas mentioned in the hypothesis part of this thesis. [17] Reported that households with high labor availability in man equivalent are more likely to adopt hand dug water harvest technology than households with low labor availability in man equivalent.

Plot distance: The result was significant at less than $1 \%$ probability level and negatively affects choice of plastic lined pond and above ground tank water storage technology. The model result showed that on average, distance of the plot from homestead increases, the agro pastoralist less likely prefer plastic lined pond and aboveground tank storage over clay lined pond (base category) of water harvesting technology by $0.86 \%$. Thus, households having plot near their home prefer plastic lined pond and aboveground tank storage because they need the day to day follow up and materials used are convenient and costly than clay lined pond. Those technology groups, which need day to day follow up, should necessarily be built near home [6]. In addition, aboveground structures are usually built near residence to collect water from roofs and plastic lined ponds also built around home garden for domestic consumptions of water and for garden crop productions.

Plot area: This variable is statically significant at $1 \%$ probability level and positively affects the choice decision of aboveground tank over clay lined pond water harvesting technology. This means that an increase of the plot area by one unit is associated with an increase in probability of choosing plastic lined pond over clay lined pond water harvesting technology by $22.3 \%$.

Furthermore, agro pastoralists with many plot area can allocate his/her plot to construct plastic lined pond water storage technology for different purpose. For instance, it can be constructed for crop production through irrigation, human consumption and livestock watering. Water harvested by plastic lined pond is safer than clay lined pond water storage technology for human consumption. [18] Reported similar results with this study that plastic lined pond of water storage technologies require relatively larger area than the clay lined pond water harvesting for their construction and effective use.

Ownership of land /plot: This variable was found be significant at $10 \%$ significance level and affects the choice of aboveground tank water storage technology negatively. Thus, households having their own land or plot have an opportunity to choice and construct water storage technology 
groups than hired because those who hired land are suspect to construct as they may leave the plot for owner after certain time limitation. Model result revealed that households who hired plot from others were less likely to construct aboveground tank over clay lined pond water storage by $8.4 \%$ as compared to the owner of the plot. The possible justification for this finding was any investment decision on residences is directly related with ownership of the land or plot and also similar report was reported in [15].

Table 8. Estimated coefficients of Multinomial logistic model.

\begin{tabular}{|c|c|c|c|c|c|c|c|c|}
\hline \multicolumn{5}{|c|}{ Multinomial logistic regression } & \multicolumn{4}{|c|}{ Number of obs $=178$} \\
\hline \multicolumn{9}{|l|}{ LR chi2 $(16)=139.71$} \\
\hline \multicolumn{9}{|l|}{ Prob $>$ chi $2=0.0000$} \\
\hline \multicolumn{5}{|c|}{ Log likelihood = -107.15261 } & \multicolumn{4}{|c|}{ Pseudo R2 = 0.3946} \\
\hline \multirow{2}{*}{ Explanatory variables } & \multicolumn{4}{|c|}{ Plastic lined pond } & \multicolumn{4}{|c|}{ Above ground tank } \\
\hline & Coefs & Std. err & z-valu & p-value & Coefs & Std. err & z-value & p-value \\
\hline TLU & 0.005 & 0.021 & 0.24 & 0.810 & 0.035 & 0.034 & 1.03 & 0.303 \\
\hline Man Equiv & $0.166^{*}$ & 0.099 & 1.66 & 0.096 & -0.107 & 0.156 & -0.68 & 0.494 \\
\hline Education & 15.921 & 918.98 & 0.02 & 0.986 & 16.302 & 918.98 & 0.02 & 0.986 \\
\hline Plot Area & 0.692 & 0.458 & 1.51 & 0.131 & $2.728 * * *$ & 0.555 & 4.91 & 0.000 \\
\hline Plot Distance & $-0.113 * * *$ & 0.039 & -2.85 & 0.004 & $-0.192 * * *$ & 0.052 & -3.67 & 0.000 \\
\hline Slope Plot & -20.249 & 3375.2 & -0.01 & 0.995 & -22.022 & 3375.18 & -0.01 & 0.995 \\
\hline
\end{tabular}

Source: Multinomial logistic model output, 2018. *** \&* shows significance at $1 \%$ and $10 \%$ probability levels, respectively

Note: Clay lined pond is set as the Base category

Dependent variable $=$ the preference of water storage technology groups

Table 9. Marginal effects of multinomial logistic model.

\begin{tabular}{lll}
\hline \multirow{2}{*}{ Explanatory variable } & Plastic lined pond & Above ground tank \\
\cline { 2 - 3 } & dy/dx & dy/dx \\
\hline Finan Short( $\left(^{\wedge}\right)$ & 0.0369372 & -0.0369 \\
TLU & -0.0032161 & 0.0032161 \\
Man Equiv & $0.0298078^{*}$ & -0.0298078 \\
Education & -0.0416702 & 0.0416702 \\
Plot Area & -0.2227835 & $0.2227835^{* * *}$ \\
Plot Distance & $-0.0086843 * * *$ & $-0.0086843^{* * *}$ \\
Slope Plot $\left(^{\wedge}\right)$ & 0.2823902 & -0.2823902 \\
Own Land $\left(^{\wedge}\right)$ & -0.0840168 & $0.0840168^{*}$ \\
\hline
\end{tabular}

Source: Multinomial logit model output, 2018

$(\wedge) \mathrm{dy} / \mathrm{dx}$ is for discrete change of dummy variable from 0 to 1

$* * * \& *$ shows significance at $1 \%$ and $10 \%$ probability levels, respectively

\section{Conclusion and Recommendation}

\subsection{Conclusion}

In the arid and semi-arid areas of developing countries there is high water shortage during dry season and thus an increasing demand for the large range of low cost agricultural water management technologies. In response to this expanding low cost rainwater harvesting technologies that can be constructed and managed at individual resource poor farm household level or community level is far important to solve water shortage problem in arid and semi-arid areas and it has potential to improve livelihoods of households through increased crop productions and water supply for livestock. In Benatsemay woreda different rainwater harvesting technologies were implemented at individual farm household level or community level to solve water shortage problem. However, water shortage problem is not addressed due to ineffective use of provided water storage technology because of ignored agro pastoralists' perception or participation and preference of water storage options mainly by excluding them from the planning and implementation stages of the rainwater harvesting technologies leading to problems related to low rates or poor adoption. To this end, this study focused on identifying factors that affect willingness of agro pastoralist's participation on water harvesting works across potential users and their preference among different water storage technology options. Consequently, Out of total 192 sample respondents, $92.7 \%$ were willing and the rest $7.3 \%$ were non-willing to participate in rainwater harvesting activities. Willing respondents were asked to reveal their preferences among water storage technology groups. 
Accordingly, $17.98 \%, 54.49 \%$ and $27.53 \%$ were preferred clay lined pond, plastic lined pond and aboveground tank respectively.

The result of the binary logistic analysis for the participation decision model revealed that out of 12 explanatory variables hypothesized, 5 variables were significant. Perception/Attitude towards the importance of water harvesting activities for food security is another significant and positively related variable to affect the willingness of sample households to participate in water harvesting works. This means that positive perception/attitude towards the importance of water harvesting technologies is an important input to decide for participation.

Labour availability is another key variable needed for constructing water storage structures and this variable is affecting the willingness of agro pastoralist to participate in water harvesting activities. It is significant and positively related with the willingness of users for participation, which indicated that availability of labour is an essential element to practice water harvesting activities.

Distance to water sources is significant and related positively with the willingness of agro pastoralists to participate in water harvesting works. As they are located at near the water source they are non-willing to participate in water harvesting activities than distant to water sources. On the contrary those distant to water sources are more willing to participate in water harvesting activities which indicates that distance to water source matters the participation decision.

Age of household head was significant and has negative association with willingness of agro pastoralist to participate in water harvesting activities. This variable as hypothesized affects the willingness of agro pastoralist to participate in water harvesting activities, in such a way that as the age of the household head increase, they are more reluctant to participate or willing to participate in water harvesting activities. Thus, the negative effect of this variable indicates that aged peoples are less willing to participate in water harvesting activities than the younger. Accessibility of credit facilities is a prerequisite for a technology to be adopted and promoted properly. It was significant and positively related to the willingness of agro pastoralist to participate in water harvesting activities. It could be concluded that credit accessibility, age of household head, perception towards water harvesting, distance to water sources and labour availability were significantly affect the agro pastoralists willingness to participate in water harvesting activities. These variables affect agro pastoralist's decision to participate either positively or negatively and determine their willingness or non-willingness to participate.

The result of the multinomial logistic analysis for the preference decision model revealed that out of 8 explanatory variables hypothesized, 4 variables were significant. Plot distance from homestead was significant and negatively affects choice of plastic lined pond and above ground tank water storage technology. Households having plot near their home prefer plastic lined pond and aboveground tank over clay lined pond storage because they need the day to day follow up and materials used are convenient and costly. On the other hand households having plot far from their home prefer clay lined pond storage over plastic lined pond and aboveground tank. Hence, distance of plot from homestead matters choice of water storage technology.

Labour availability was significant and positively affects choice of plastic lined pond of water harvesting technology over clay lined pond. Agro pastoralists who have large labour force would prefer plastic lined pond over clay lined pond of water harvesting technology. This is because using plastic lined pond water harvesting technology is more labours work and comparatively important for livestock watering, human consumption and crop production than clay lined pond and requires more labour force for activities such as irrigation, drinking water for humans and livestock.

Plot area is statically significant and positively affects the choice decision of aboveground tank over clay lined pond water storage technology. Aboveground tank water storage requires enough plot area and can be constructed for human consumption and livestock watering more effectively than clay lined pond as water harvested by aboveground tank is safer than clay lined pond water harvesting technology for human consumption.

In general, these significant variables such as labour availability, ownership of plot, plot area and plot distance matters for choice decision making among alternative water storage technology groups to be constructed.

As revealed in study result, $83.85 \%$ of respondents reported that in their house females are responsible to fetch water of whom $77.6 \%$ are willing and $6.25 \%$ are not willing to participate in water harvesting activities. Thus, Women play a crucial rule in water provision as they are the ones fetching the water in agro pastoralist areas.

\subsection{Recommendation}

For successful implementation and expansion of rain water harvesting practice to solve water shortage problems and better adoption rate by the users benefiting from it, the following recommendations are made.

The government and other development organizations have to focus on agro pastoralists' perception or participation because positive perception or attitude towards water harvesting is an issue of technological convenience and acceptance by the users for proper adoption and implementation of water harvesting technology. Poor perception of the users towards water harvesting technologies or the limitation of knowhow at the initial years of dissemination would cause failure of the water harvesting technology implemented. Therefore, prioritizing their perception or participation, awareness creation and enabling them to participate in water harvesting activities would enable effective use of implemented rainwater harvesting technology. 
Credit access of the agro pastoralist households is another key factor explaining the decision behavior of agro pastoralist for participation in water harvesting works. Those households who lack credit access were not willing to participate in water harvesting activities. Working to alleviate the credit access of users is, therefore, essential for policy makers and other NGOs to promote water-harvesting practices in the long run. This can be carried out using various means, one of which is provision of adequate loan with possible minimum interest rates.

To implement water storage technology at farm household level or community level it would be necessary to point toward the preference of agro pastoralist households among alternative water storage technology options based on the characteristics of a plot area, plot distance from home stead, labour availability and ownership of plot. These characteristics change preference decision of users among water storage technology groups. Therefore, experts and policy makers should consider preference of users while developing and promoting water storage technology options through focusing on the characteristics of a plot area, plot distance from homestead, labour availability and ownership of particular plot.

It may well that government and NGOs provide plastic lined pond water storage technology with roof covers as they frequently revealed their preference based on characteristics of a their plot area, plot distance from homestead, labour availability and ownership of particular plot. And also government has to equip them by materials and gave training about how effectively use as well ordering them to do fence around pond to protect any danger of livestock or humans.

Finally, it is important to incorporate women's technology interaction in water harvesting technologies and current policies both locally at community levels, and at government and development partner level because women's are essentially closer to the rain water harvesting technologies and their work entails a close relationship with them. They relate directly and are in constant interaction with the technologies in their daily activities for subsistence needs especially food production, and the search for water.

\section{Acknowledgements}

I acknowledge Jinka Agricultural Research Center for financing this study particularly center director Muhaba Sultan for his heartfelt help in facilitating snug working environment and encouragement.

\section{References}

[1] UN-HABITAT. Rainwater Harvesting and Utilisation. Blue Drop Series, Book 2: Beneficiaries\&Capacity Builders. Retrieved from Website: www.unhabitat.org.
[2] International Food Programme Research Institute (2010). Access to improved water source and satisfaction with services, discussion paper Evidence from rural Ethiopia. Addis Ababa, Ethiopia.

[3] International Symposium on Rainwater Harvesting (2015). Unlocking the Potential of Rainwater Harvesting with Adaptive Strategies and Impact for upscaling. Proceedings of the International Symposium on Rain water Harvesting and Resilience 2015. Addis Abeba; June 1-12, 2015. Eline, B., and Josep, T. (ed.), Addis Abeba: Ethiopia.

[4] International Water Management Institute (2009). Irrigation Methods: Surface Irrigation-Options for smallholders. Module 5, part I. Addis Abeba: Ethiopia.

[5] Food and Agricultural Organization of united Natios (2016). Rapid cross-border drought assessment. FAOsIntergovernmental Authority on Development, Ethiopia Kenya - Somalia

[6] Martinson, D. B., Ranatunga, N. U. K., and Gunarante, A. M. C. H. A. (2002). Reducing rainwater harvesting system cost, Sustainable environmental sanitation and water services, 28th WEDC conference. Calcutta: India.

[7] South omo zone pastoral and agro pastoral development office (2017). Socioeconomic and demographic characteristics of South omo zone, Jinka.

[8] Kothari, C. (2004). Quantitative Techniques. New Delhi: Vikas Publishing House Pvt. Ltd.

[9] Gujarati, D. N. (2003). Basic Econometrics (4 ${ }^{\text {th }}$ ed.). New York: The McGraw-Hill, Inc.

[10] Verbeek, M. (2004). A Guide to Modern Econometrics (2 $2^{\text {nd }}$ ed.). Erasmus University Rotterdam: John Wiley \& Sons Inc.

[11] Greene, W. H. (2000). Econometric Analysis (4 ${ }^{\text {th }}$ ed.). USA: Prentice Hall International, Inc.

[12] Greene, W. H. (2007). Econometric Analysis (6 $6^{\text {th }}$ ed.). New York University: Pearson Education, Inc.

[13] Baiyegunhi, L. J. (2015). Determinants of rainwater harvesting technology (RWHT) adoption for home gardening in Msinga, KwaZulu-Natal, South Africa. Water SA, 41,1 .

[14] Abadi, T. (2006). Analysis of Social, Economical, and Institutional issues affecting utilization of rainwater harvesting technology, Eastern Tigray, Ethiopia. Master'sThesis School of Graduate Studies of Alemaya University, Alemaya.

[15] Araya, A. (2013). Factors affecting household's decision to adopt roof water harvesting practices as a source of domestic water supply. Mekelle, Ethiopia. Master's Thesis Submitted to Mekelle University, Mekelle.

[16] Wooldridge, J. M. (2002). Econometric Analysis of cross sectional and panal data. Massachusetts London, England: The MIT Press Cambridge, 498-499.

[17] Yismashewa, F. (2014). Assessment of factors affecting adoption of water harvesting technology: Case of Damota Kebele Haramaya Woreda, East Haraghe, Oromia Region. Master's thesis submitted to Haramaya University, Haramaya. 
[18] Molla, T. (2005). Farmers' response and willingness to participate in water harvesting practices: a case study in Dejen district / East Gojam Zone. Master's thesis submitted to Alemaya University, Alemaya. 